УДК 637.51.033:579.864:579.264

\title{
ВПЛИВ МОЛОЧНОКИСЛИХ БАКТЕРІЙ НА ПОВЕРХНЕВУ МІКРОБІОТУ М'ЯСА
}

Л.Г. Віннікова, доктор технічних наук, професор*

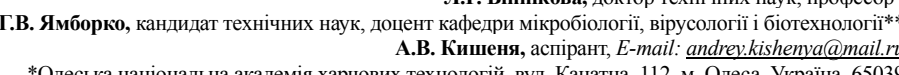

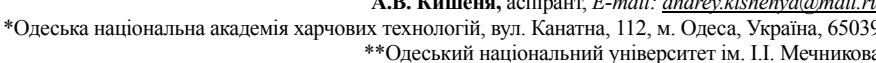

Анотація. У статті наведено результати досліджень впливу різних штамів молочнокислих бактерій роду Lactobacillus plantarum на можливість пригнічення власної патогенної мікрофлори м'яса. Проби охолодженого м'яса відбирали на вироє найбільш мікробіально забрудненими. Псування охолоджених продуктів (зокрема м’яса) відбувасться насамперед внас док життедіяльності великої кількості мікроорганізмів: бактерій, грибів (плісняви, дріжджі), вірусів та мікропаразитів. У роботі для подовження строку зберігання продукту використовували альтернативні хімічним препаратам сполуки - речовини мікробіологічного походження (бактеріоцини, ферменти). Визначено кількісний та якісний склад поверхневоі мікрофлори м'яса. Встановлено антагоністичну дію молочнокислих мікроорганізмів на гнильну мікробіоту м'яса. За результаталовості в якості білологіного бар'єру шо дозволить уповільнити розвиток патогенної мікрофрори

Ключові слова: мікробіота м'яса, Lactobacillus plantarum, строк зберігання, антагоністична дія.

\section{ВОЗДЕЙСТВИЕ МОЛОЧНОКИСЛЫХ БАКТЕРИЙ НА}

\section{ПОВЕРХНОСТНУЮ МИКРОБИОТУ МЯСА}

Г.В. Ямборко, кандидат технических наук, доцент Л.Г. Винникова, доктор технических наук, профессор А.В. Кишеня, аспирант, E-mail: andrey.kishenya@mail.r. * Одесская национальная академия пищевых технологий, ул. Канатная, 112, м. Одеса, Украина, 65039
** Одесский национальный университет им. И.И. Мечникова

Аннотация. В статье приведены результаты исследований влияния различных штаммов молочнокислых бактерий рода Laclobaln часть), поскольку эти участки являются наиболее микробиального загрязненными. Порча охлажденных продуктов (в частности мяса) происходит прежде всего в результате жизнедеятельности большого количества микроорганизмов: бактерий, грибов (плесени, дрожжи), вирусов и микропаразитов. В работе для продления срока хранения продукта использовали альтернативные химическим препаратам соединения - вещества микробиологического происхождения (бактериоцины, ферское действие мопочнокислых микроорганизмов на гнилостную микробйоту мяса По результатам опытов докозастиче ское действие молочнокислых микроорганизмов на гнилостную микробиоту мяса. По результатам опытов доказано, что ческого барьера, что позволит замедлить развитие патогенной микрофлоры.

Ключевые слова: микробиота мяса, Lactobacillus plantarum, срок хранения, антагонистический эффект.

Copyright $\odot 2015$ by author and the journal "Food Science and Technology"

This work is slicensed under the CCeative Commons Attribution International License (CC BY)
http://creativecommons.org/licenses by/4.0

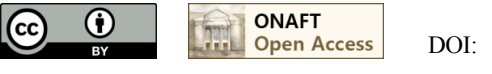 \\ BстуII}

Тривале забезпечення якості і безпечності продукцій $\epsilon$ першочерговою метою для спеціалістів м'ясної промисловості. Свіже м'ясо має досить обмежений термін зберігання, що створює труднощі для виробників створює потенційну загрозу для споживачів. У зв'язку цим зоут м'ясної продукції територіально обмежений місдем виробницива і прилеглми регіонами, а трансТермін зберігання м'ясних продуєтів с важсивия

Терміи зберігін м'

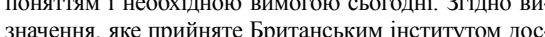
ліджень у галузі харчових технологій (UK Institute of
Food Science and Technology, IFST) [2] - це період часу, протягом якого харчовий продукт залишасться

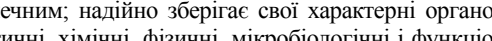
ептичні, хімічні, фізичні, мікробіологічні і функціоним про харчову цінність при його зберіганні в рекомим про харчову цін
мендованих умовах.

\section{Постановка проблеми}

Виробництво м'ясних продуктів завжди було і зарудомісткою і високовартісною галуззю. Однак у процесі зберігання та реалізації м'ясні про- дукти зазнають цілий ряд змін, до яких відноси
обсіменіння поверхні небажаної мікрофлорою.

Основними ініціаторами мікробних уражень поверхні м'ясних продуктів виступають цвілеві гриби поверхнева мікрофлора, що володіють високою здат ністю до спороутворення. Саме ці мікроорганізми погіршують органолептичні показники продукції, викликають зміни в складі білків, жирів, продукують исокотоксичні речовини.

Тому розвиток промислового виробництва ставить барше місце проблеми збереження якості та збільрозня термінів придатності м' яса та м'ясопродуктів, строків зберігания м'sсних продуктів представляс собою науковий та практичний інтерес [3]

Виходячи 3 вищенаведеного метою даної роботи було вивчення здатності бактерії роду Lactobacillus пригнічувати розмноження мікроорганізмів, які спричиняють псування м'яса.

\section{Літературний огляд}

Біотехнологічні процеси 3 використанням мікроорганізмів і ферментів уже на сучасному технічному
рівні широко застосовуються у харчовій промисловорівні широко застосовуються у харчовій промисловолинних і тваринних клітин використовують для оле линних 1 тваринних кллтин використовують для оде-
ржання активних сполук - ферментів, гормонів, амінокислот, вітамінів, антибіотиків, метанолу, органічних кислот (оцтової, лимонної, молочної). Частину традиційних промислових технологій заміняють технологіями, що передбачають застосування ферментів 1 мікроорганізмів [4].

Молочнокислі бактерії широко використовуються в багатьох галузях харчової промисловості. Завдяки утворенню великої кількості молочної кислоти, до якоі самі вони в значній мірі толерантні, молочнокислі бактерії за підходящих умов можуть доволі швидко ро ній причині їх легко гультин мирортанізм. lo У

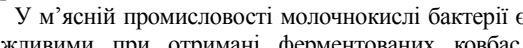
оскільки вони проявляють фозитивтой виих ковбас, систенцію і в'язкість ковбасного фаршу.

Один із можливих способів дії молочнокислих мікроорганізмів, результатом якого $\epsilon$ придушення небажаної й становлення певної мікрофлори, це виділення антибактеріальних речовин, таких як органічні кислоти, діоксид вуглецю, пероксид водню, диацетил, а також бактеріоцинів. Цим пояснюеться іхня комплексна антимікробна дія, що дає можливість іх використовувати у якості природних консервантів продуктів харчування. Бактеріоцини педіококів, педіоцини, активні проти Listeria i мають значний потенціал у якості біоконсерванту для м'ясної промисловості [5]

Для ефективного застосування бактеріоцинів

Харчова науга і технологія тивність і стабільність цих сполук, цілеспрямовано одержувати бактеріоцини 13 заданими властивостями Молочнокислі бактерії Lactococcus, Lactobacillus,

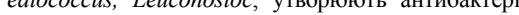
льні речовини, зокрема бактеріоцини, які можуть ви.

Висока пристосовуваність молочнокислих бактерій до умов нового середовища життя дозволяе імм рзвиватися в м'ясі, м'ясних продуктах і розсолах.

Застосування селекціонованих рас відкривас перс-

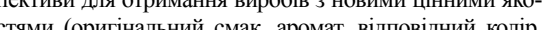
стями (орипінальний смак, аромат, відповідний колір

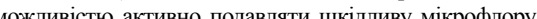
шо розвивасться на м'ясних продуктах [6]

Потребує уваги вивчення м'яса і м' ссних продуктів як середовиша для розвитку молочнокислих організмів з метою оптимізації в них умов для максимального виявлення корисних функцій мікроорганізмів.

\section{Основна частина}

Метою роботи було вивчення здатності бактерії роду Lactobacillus пригнічувати розмноження мікроорганізмів, які спричиняють псування м'яса.

М'язова тканина здорових тварин теоретично мас бути стерильною. Проте при забої тварин в умовах м'ясокомбінату м'ясо зазвичай містить різну кількість мікроорганізмів [7]. Ця мікробіота може бути результатом ендогенного (прижиттевого) або екзогенного (після убійного) шляхів обсіменіння. Ендогенне обсіменіння органів і тканин здорових тварин відбувається в основному протягом життя тварин та пов'язане із зниженням природної опірності організму, яке відбувається під впливом різних неблагоприемних чинників. Джерелами екзогенного мікробного обсіменіння м' яса слугують шкіра тварин, шлунково-кишковий тракт, устаткування, руки i

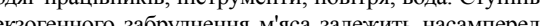
від дотриання санітарних правил i технології оброблення туш [8].

Відповідно до сучасних нормативних документів у м'ясній промисловості регламентуються такі мікробіологічні показники: мезофільні аеробні і факультативно-анаеробні мікроорганізми, бактерії групи кишкової палички (представники родів Escherichia, Klebsiella, Enterobacter, Citrobacter, Serratia), умовнопатогенні мікроорганізми (бактеріі роду Proteus, коагулазонегативні стафілококі, Bacillu scereus, Clostridium perfringens) [9].

Згідно з результатами проведених досліджень бактеріологічні показники усіх проб сирого м'яса забойних тварин взагалі задовільні та відповідають у всіх дос. Слід вддмітии, що кількість МАФАнМ у всіх досліджуваних зразках не підвищувала допуспроб Proteus (табл. 1). 
Табллиц 1 - Показники мікроб̈іологічного контролю охолодженого м'яса

\begin{tabular}{|c|c|c|c|c|c|}
\hline \multirow{2}{*}{$\begin{array}{c}\text { Найменування досліджуваного } \\
\text { об'єкту }\end{array}$} & МАФАнМ & \multicolumn{4}{|c|}{ Кількість проб, в яких виявлені } \\
\cline { 3 - 6 } & бГКП & $\begin{array}{c}\text { Eaктерії роду } \\
\text { Salmonella }\end{array}$ & $\begin{array}{c}\text { Staphylo } \\
\text { coccus aureus }\end{array}$ & $\begin{array}{c}\text { Бактерии рода } \\
\text { Proteus }\end{array}$ \\
\hline $\begin{array}{c}\text { М'ясо свіже (усі види забійних } \\
\text { тварин) та охолоджене у відрубах }\end{array}$ & $\begin{array}{c}1.10^{2}-1.10^{3} \\
\text { (у межах норми) }\end{array}$ & 1 & - & - & 1 \\
\hline
\end{tabular}

Найчастіше із нестандартних проб виділяли бактерії родів Klebsiella i Proteus, а бактерій роду Salmonella і токсигенних стафілококів у жодній проб̆ виявлено не було. Що стосуеться виявлення БГКП, то основними мікроорганізмами ціеї

М'ясо, отримане при забої здорових, угодованих, неутомлених тварин 3 дотриманням санітарних $\mathrm{i}$ технологічних вимог, зазвичай містить мікроорганізми лише на поверхні, що пов'язано 3 екзогенним обсіменінням в процесі оброблення туші [10]. При вивченні якісного складу поверхневої мікробіоти охолодженого м'яса було визначено, що термофіли і частина мезофільних мікробів загинули, проте велика чисельність мезофілів залишилися ум'ясі. Такимй
представники бактерій з роду Bacillus (рис. 1).

редставники бактерій з роду Bacillus (рис. 1). Також у встановленому температурно-вологовому режимі зберігання в охолодженому м' ясі активно ролички роду Pseudomonas ma Achromobacter, аероб коки роду Місгососсич. Бупо визначено, що найактивніше розмножувалися бактерії роду Рseudomonas, які володіють антагоністичними властивостями відносно інших мікроорганізмів, Згінно літературния даним багато патогенних мікроорганізмів - золотистий стафілокок, сальмонели, збудник ботулізму зберігають життездатність у охолодженому м'ясі [6], проте у наших дослідженнях дані мікроорганізми виявлені не були.

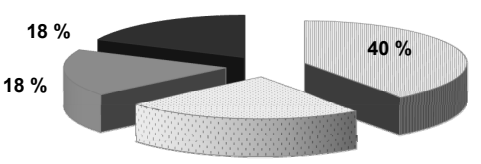

$24 \%$

$\square$ Basillus spp.

$\square$ Pseudomonas spp.

\section{Achromococcus spp.}

Рис. 1. Частота виявлення представників поверхневої мікробіоти охолодженого м'яса.

Домінуюча група поверхневої мікробіоти охолодженого м'яса - бактерії роду Bacillus були представлені грампозитивними короткими паличками із завишують розмір клітини, розташовані центратьно (рис. 2)

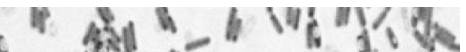

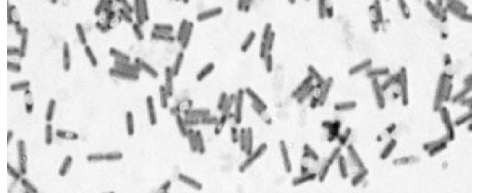
$129 \%$

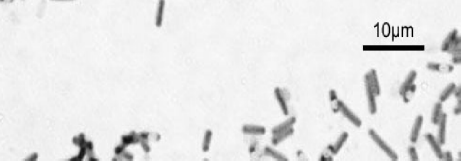

a)

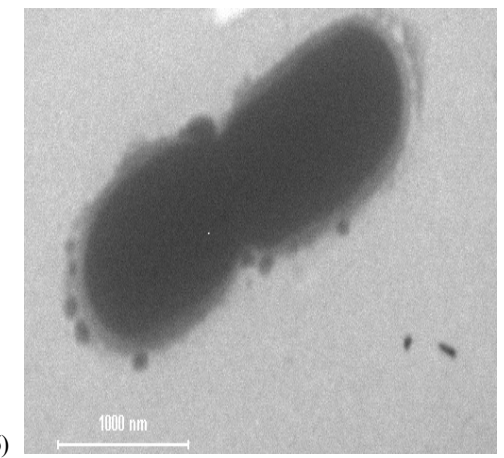

Рис. 2. Мікроскопічний препарат a) фарбований за методом Грама (х1000) б) електронно-мікроскопічний (х4500).

На м'ясопептонному агарі (МПА) Bacillus spp.I утворювали сухі, дробнозморшкуваті, бархатисті досліджувані штами роду Bacillus були грампозитивні, рухливі, не утворювали параспоральні кристали, характеризувалися здатністю до росту за $30-40$ С та його відсутністю за $5 \mathrm{C}$, утворювали каталазу росли у м'ясопептонному бульйоні (МПБ) з $2-10 \% \mathrm{NaCl}$ та $\mathrm{pH} 6,8$, розкладали нітрати до нітритів, не утилізували цитрат, не утворювали індол та були негативн за тестом Вогеса-Проскауера. Характерною властивстю ізольованих 5 штамів Bacillus spp. була відсутність анаеробного росту.

Псування охолоджених продуктів (зокрема м'яса) відбувасться насамперед внаслідок життедіяльності

великої кількості мікроорганізмів: бактерій, грибів, вірусів та мікропаразитів. Дослідження властивостей харчових бактерій-пагогенів свідчить про те, що вони проявляють стійкість до антибактеріальних агентів, технологічним режимам обробки і внесеним інгредієнтам. Для пригнічення або уповільнення розвитку різних мікроорганізмів застосовують традиційні методи, такі як холод, високі температури, антисептики, ультрафіолетове і радіоактивне опромінення, СВЧ-

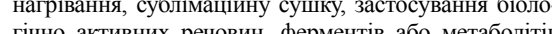
rispo Topy uactying

Тому наступим етапом нашої роботи була пере-

Таблиця 2 - Антагоністична активність досліджуваних лактобактерій

\section{Індикаторний Діаметр затримки росту індикаторних мікроорганізмів, мм}

\begin{tabular}{|l|l|l|l|l|} 
мікрорганізм & L. plantarum ONU 12 & L. plantarum ONUL 87 & L. plantarum ONU 469 & L. plantarum VTCCB 0921 \\
\hline
\end{tabular}

\begin{tabular}{|l|c|c|c|c|}
\hline Bacillus spp. 1 & $20,0 \pm 1,4$ & $19,0 \pm 0,5$ & $18,1 \pm 1,5$ & $17,0 \pm 1,1$ \\
\hline Bacillus spp. 2 & $15,0 \pm 1,2$ & $7,4 \pm 1,0$ & $5,0 \pm 0,5$ & $14,2 \pm 1,2$ \\
\hline Bacillus spp. 3 & $14,2 \pm 1,2$ & $8,1 \pm 1,4$ & $10,3 \pm 1,3$ & $14,0 \pm 1,6$ \\
\hline Bacillus spp. 4 & $15,3 \pm 1,7$ & $7,0 \pm 1,3$ & $13,0 \pm 1,2$ & $17,5 \pm 1,1$ \\
\hline Bacillus spp.5 & $13,5 \pm 1,4$ & $13,3 \pm 1,2$ & $14,0 \pm 1,1$ & $11,2 \pm 1,4$ \\
\hline
\end{tabular}

Bacillus spp.5

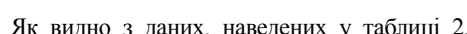
там $L$ : $\begin{array}{ll}\text { штам L. Plantarum ONU12, ізольований з виноград- } & \text { ганізмів. Діаметр зони затримки } \\ \text { ного сусла, володів максимальною антагоністичною } & 13,5 \pm 1,4 \text { до 20,0 } \pm 1,4 \text { мм (рис. } 3 \text { ). }\end{array}$

активністю по відношенню до індикаторних мікроор-

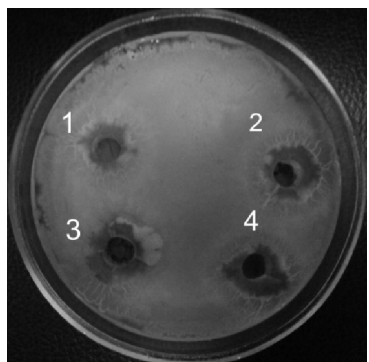

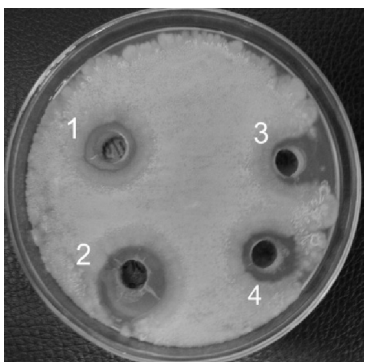

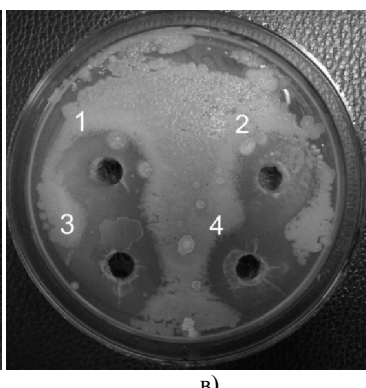

Рис. 3. Зони затримки росту дослідженими штаммами Lactobacillus plantarum ONU469 (1), Lactobacillus plantarum ONU12 (2), Lactobacillus plantarum VTCCB 0921 (3), Lactobacillu splantarum ONUL 87 (4): a) Bacillus spp. 1, б) Bacillus spp. 2 та в) Bacillus spp. 3.

\section{Висновки}

Згідно з результатами проведених достінень (1) бойних тарин взагал усх проб сирого м'яса завірмітити, шо гільгість МАФАнМ у всіх досліржуваних зразках не пілвищувала допустимі величини, а нестантартними вванали олиничн проби внастілок виявтення БГКП, бактерій роду Proteus. Найчастіше всього із нестандартних проб виділяли бактерії родів Klebsiella $\mathrm{i}$ Proteus, а бактерій роду Salmonella і токсигенних стафілококів у жодній пробі виявлено не було. Що стосуеться виявленн

Харчова наука і технологія
БГКП, то основними мікроорганізмами цієї групи, які виділялися з усіх досліджуваних проб, були бактерії родів Klebsiella ma Enterobacter. Після виділення і ідентифікації поверхнеаої мікробіоти мяса перевіряли антагоністичний ефект $L$. Plantarum по відношенню до тест-культур. Таким чином, проведені дослідження свідчать про те, що молочнокислі мікроорганізми $L$. plantarum ONU12 та L. plantarum відношенд данні погезують можливість використани даних

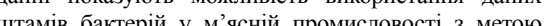


збільшення терміну зберігання та контролю мікробі- ологічного забруднення м'яса та м’ясопродуктів. Список літератури:

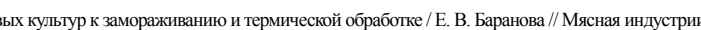

Jeremiah L. E. Extension of Chilled Pork Storage Life, Agri-Food Canada Research Center / L. E. Jeremiah // Natoinal Pork Producers Coucill- - № 497P. $1-8$

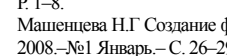

4. Gagri A. Antimicribial edible films and coatings / A. Gagri, Z. Ustunol, E. T// Jounal of Food Protection. - vol 67. №4_-2004-P. 833-848.

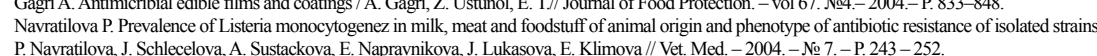

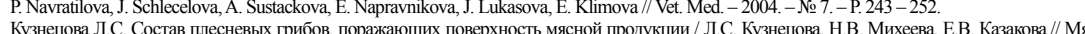
ная индустрия - - 두 Март- - 2009.-С. 28-31. Vogel R. F. et al. The competitive advantage of Lactobacillus curvatus LTH 1174 in sausage fermentation is caused by formation of curvacin // A. Sy 1999.- № 50 . - - P. 131-149. Егоров Н. С. Микробы-антагонисты и биологиче ские методы определения антибиотической активности. - М.: Высшая школа, 2009. - С. 28 10. Cagri A., Osburn Inhibition of Listeia monocytogrnes on hot dogs using antimicrobial whey protin-based edible coatings / A. Cagri, Z. Ustunol. / / Jourmal of Food Protection-- Vol 68. №2.-2003--P. 291-299. Костенко Ю.Г. Санитарно-микробиологические аспекты производства охлажде

\section{DETERMINE THE EFFECT OF LACTICACIDBA CTERIAON}

THE SURFACE MICRO FLORA OF MEAT

G.V. Yamork T.G. Vinnikov, Ph.D., professor * A.V. Kyshenya, a graduate student, E-mail: andrey.kishenya@mail.

* Odessa National Academy of Food Technologies, Kanatnaya str., 112, Odesa, Ukraine, 65039 Odessa National University II Mechniko

Annotation. This paper presents the results of research concerning the possible impact of different strains of lactic acid bacteria of the family Lactobacillus plantarum on suppressing the meat's own pathogenic microflora. Specimens of chilled meat were collected on the production plant from different parts beef carcass (middle neck, flank, hip), because microbial contamination of these parts is considered to be the highest one. Qualitative and quantitative composition of the surf

Spoilage of refrigerated products (especially meat) occurs primarily as a result of vital activity of a great number of microorganisms: bacteria, fungi (mold, yeast), viruses and microparasites. Today, to preserve the product, innovative technologies are needed

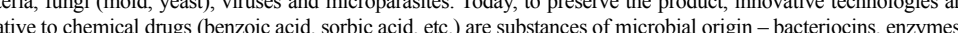

The research findings show that lactic acid bacteria of Lactobacillus plantarum family can be used in meat industry as a biologcal barrier will slow down the development of pathogenic microflora.

\section{References}

Reva EV Povyishenie ustoychivosti startovyih kultur k zamorazhivaniyu i termicheskoy obrabotke. Myasnaya industriya 2009; 9: 70-72.

Jeremiah LE Extension of Chilled Pork Storage Life. Natoinal Pork Producers Coucill 1997:4: 1:8

. Mashentseva NG Sozdanie funktsionalnyih bakterialnyih preparatov dlya myasnoy promyishlennosti. Myasnaya industriya. 2008; 1:26-29. Gagri A, Ustunol Z, Ryser ET Antimicribial edible films and coatings. Journal of Food Protection. 2004; 4: 833-84

Navratilova P, Schlecelova J, A. Sustackova A, Napravnikova E, Lukasovva J, Klimova E Prevalence of Listeria monocytogenez in milk, me Kuznetsova LS, Miheeva NV, Kazakova EV Sostav Plesnevyih gribov, porazhayuschih poverhnost myasnoy produktsii. Myasnaya industriya 2009; 3: 28-31 Nogel R. Pohle B., Tichaczek PS The competitive advat Caplice $\mathrm{E}$ Food fermentations: Role of microorganisms in food production and preservation. Food Microbiol. 1999; 50: $131-149$

Egorov NS Mikrobyi-antagonistyi ibiologicheskie metodyi opredeleniya antibioticheskoy aktivnosti. - M. . Vyisshaya shkola; 2009 .
Cagri Z Ustunol W O Obsurn Inhhibition of Listeia monocytogrnes on hot dogs using antimicrobial whey protrin-based edible coatings. Journal of

1. Kostenko YuG Bataeva DS Krasnova MA Sanitarno-mikrobiologicheskie aspektyi proizvodstva ohlazh-dennoy svininyi dilitelnogo srok godnosti. Myasnaya industriya. 2014; 4: 66-67

Отримано в редакцію 1.06 .2015
Прийнято до друку 3.08 .2015
УДК 663.22:661.971

\section{МЕТОД ВИЗНАЧЕННЯ ІГРИСТИХ ВЛАСТИВОСТЕЙ ВИНА}

О. Б. Ткаченко, доктор технічних наук, доцент *,E-mail: oksana_tkachenko@mail.rm C.C. Древова, аспірант *, E-mail:svetik_shum@mail.r. в.П. Железни A.Г. Нікулін, кандидат технічних наук, молодший науковий співробітник **, E-mail: arteomng@gmail.com
* Kaфедра технології вина і енолог * Кафедра технології вина і енолог

Одеська нашіннальна академія харчових технологій, вул. Канатна, 112, г. Одесса, Україна, 65039

Анотація. У статті представлено опис удосконаленого методу оцінки показників якості ігристих властивостей вина,

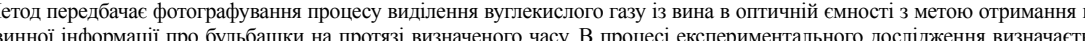
час появи бульбашки, ї розмір та глибина занурення. Запропоновано методику обробки отриманих експериментальних да(1)

Запропоновано дві математичні моделі, що описують процес зміни концентрації бульбашок та середнього діаметру бу-

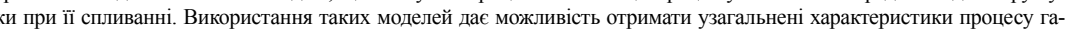
зовиділення. В роботі представлено результати опису динаміки газовиділення та зміни розмірів бульбашок в часі. Показано, що моделі дозволяють адекватно описувати процеси появи, росту та спливання бульбашок з використанням малоі кількості параметрів. Запропоновані моделі рекомендовано використовувати для кількісної та об' єктивної оцінки ігристих выKin

ові слова: ігристі властивості, бульбашки діоксиду вуглецю, експериментальна установка, матеметична модель, розпізнавання бульбашок

\section{МЕТОД ОПРЕДЕЛЕНИЯ ИГРИСТЫХ СВОЙСТВ ВИНА}

О.Б. Ткаченко, доктор технических наук, доцент*, E-mail:oksana tkachenko@mail.ru C.C. Древова, аспирант*, E-mail: svetik shum@mail.ru
в.П. Железный, доктор технических наук, профессор**, E-mail: vzhelezny@mail.ru : loztar@arambler.ru A.Г. Никулин, кандидат технических наук, младший научный сотрудник**, E-mail: arteomng@gmail.com
*Кафедра технологии вина и энологии
** Кафедра теплофизики и пикладной экологии
Одесская национальная академия пищевых технологий, ул. Канатная, 112, г. Одесса, Украина, 65039 A.Г. Никулин, кандидат технических наук, младший научный сотрудник**, E-mail: arteomng@gmail.com
*Кафедра технологии вина и энологии
** Кафедра теплофизики и пикладной экологии
Одесская национальная академия пищевых технологий, ул. Канатная, 112, г. Одесса, Украина, 65039 Аннотация. В статье представлено описание усовершенствованного метода оценки показателей качества игристых свойств вина. Метод основан на фотографировании процесса выделения углекислоты из игристого вина в оптической ячейке с целью получения первичной информации о поведении пузырьков в течении определенного времени. В процессе на методика обработки полученных экспериментальных данных методами «компьютерного зрения

Предложены две математические модели для описания процессов изменения концентрации пузырьков и среднего диа-

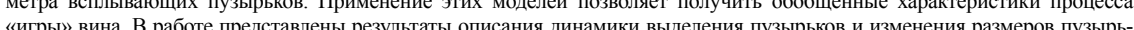
ков во времени. Показано, что модели позволяют адекватно описывать процессы образования, роста и всплытия пузырьков с использованием небольшого количества параметров. Предложенные модели рекомендуется использовать для количественной и объективной оценки игристых свойств вина.

Ключевые слова: игристые свойства, пузырьки диоксида углерода, экспериментальная установка, математическая мо-

Copyright $\mathrm{O} 2015$ by author and the journal "Food Science and Technology" :

This work is lictnsed ander the Creative Commons Attribution International License (CC BY) (c) (i)

Введение

Игристые вина - это вина, пенистые и игристые свойства которых образуются в результате насыщедения в пронессе бронении под давлением сусла или

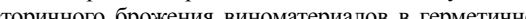

Харчова наука і технологія закрытых емкостях. Углекислый газ в жидкости находится в трех формах: газообразной, растворенной и связанной, которые имеют ряд особенностей формирующих типичные свойства вич.

отся важнейшей характестикой, которая учитрается в системе органолеп- 